\title{
Trade Policy and Women in the Pacific Alliance
}

\author{
Dorotea López* \\ Felipe Muñoz**
}

\begin{abstract}
The relation between trade and gender is complex, and has not been deeply analysed in the case of Latin American countries. Mainstream economics argue that trade is gender-neutral, but the discussion should focus whether trade policy could be oriented to foster women's economic inclusion. It is well known that, with the adequate policies, women's economic empowerment could positively impact economic growth and reduce poverty, and therefore, trade policy may become an instrument to achieve this objective. The Pacific Alliance, a novel integration scheme, has considered women economic inclusion into their work and objectives. In this article, we aim to review trade policies implemented at regional and domestic level amongst the four Pacific Alliance member countries: Colombia, Chile, Mexico and Peru. For this, the article is divided as follows. The first section reviews the literature on trade policy and gender issues, specifically in women inclusion aspects. The second section presents those policies discussed and implemented at the Pacific Alliance. The third section individually reviews member countries trade policies on women economic inclusion and empowerment. Finally, we present some conclusions and policy recommendations.
\end{abstract}

Keywords: Trade and gender, Pacific Alliance, women economic empowerment.

\section{Política comercial y mujer en la Alianza del Pacífico}

\section{RESUMEN}

La relación entre comercio y género es compleja, y no ha sido analizada profundamente en el caso de los países de Latinoamérica. La teoría económica argumenta que el comercio es neutral al género, pero la discusión debe enfocarse en si es posible que la política comercial se

\footnotetext{
* Profesora asociada de la Universidad de Chile, titular de la Cátedra OMC. Ph. D. en Ciencias Sociales en la Universidad de Chile. M. Phil en Economía, Universidad de Cambridge; B.A. en Economía, ITAM. Correo electrónico: dolopez@uchile.cl

${ }^{* *}$ Profesor asistente, Universidad de Chile. Maestría en Estudios Internacionales, Universidad de Chile. B.A. en Economía, Universidad de Chile. Correo electrónico: fmunozn@uchile.cl
} 
oriente en promover la inclusión económica de las mujeres. Se conoce que, con las políticas adecuadas, el empoderamiento económico de las mujeres puede impactar positivamente en el crecimiento económico y la reducción de la pobreza; por lo tanto, la política comercial puede ser un instrumento para lograr este objetivo. La Alianza del Pacífico, un novedoso esquema de integración, ha considerado la inclusión económica de las mujeres dentro de su trabajo y objetivos. En este artículo, revisaremos las políticas comerciales implementadas a nivel regional y domestico por cada uno de los cuatro países que conforman la Alianza del Pacífico: Colombia, Chile, México y Perú. Para esto, el artículo se divide de la siguiente manera. La primera sección revisa la literatura acerca de la política comercial y temas de género, específicamente relacionado con la inclusión de las mujeres. La segunda sección presenta las políticas discutidas e implementadas en la Alianza del Pacífico. La tercera sección revisa individualmente en cada miembro, las políticas comerciales referentes a la inclusión económica de las mujeres y su empoderamiento. Finalmente, presentamos algunas conclusiones y recomendaciones.

Palabras clave: Comercio y género, Alianza del Pacífico, empoderamiento económico de la mujer.

\section{Introduction}

Mainstream economics argues that trade is gender neutral; this has been a very controversial issue. Trade policy has been blamed to be gender blind and that it has to move into gender inclusive orientation. The relationship between gender and trade policy is still a very complex issue; even though we can find some literature, the study of trade and gender relations is still in its infancy, particularly regarding Latin America (Villup, 2017).

Facts demonstrate that women inclusion in economic activity is something that, as societies, we should be concerned about. Women participation in labor force remains an important untapped resource throughout the world, and there is an urgent need to find new sources of growth in the region. Increasing women participation in economic activities would help boost income levels and reduce poverty, as women's economic participation implies more jobs and more economic autonomy (Novta $\&$ Wong, 2017; WTO, 2017).

There is conclusive evidence that economic development and social equality go together (World Bank, 1994). This is fundamental to have a better understanding of the opportunities and challenges women face in trade policy. Trade seems to be theoretically neutral, however many studies demonstrated that, with adequate domestic policies, it could reduce gender gaps and increase women economic participation. Trade policy 
could be a strategy to increase women economic participation and the achievement of the positive spillovers that this brings, can create opportunities to accomplish this objective. Trade reforms can either enhance gender-equalizing trends or exacerbate existing gender gaps, depending on the way they are designed and implemented.

This is of particular relevance for Latin America (LA), still the most unequal region in the world where the richest $10 \%$ of the population had the $71 \%$ of the region's wealth in 2014. For many LA countries, trade liberalization has become one of the main economic policies in their development strategies; therefore, analyzing the gender impact of these kinds of policies becomes fundamental in order to understand the drivers for development. Particularly in the Pacific Alliance (PA), conformed by Chile, Colombia, Mexico and Peru, which is one of the regional integration schemes recognized by its advances and work on gender and trade issues.

However, gender inequalities within the PA member countries are worrying, with different stages of development (OCDE, 2016). Nevertheless, there is a high commitment on reducing gender gaps, both as a group and individually. In the last years, member economies have developed different strategies in order to create trade inclusive policies for women, including gender chapters' inclusion in free trade agreements, implementation of different tailored exports promotion policies or creating a gender department in their trade related institutions.

Together with the relevance of overcoming gender inequalities, the four Pacific Alliance members have identified trade on services as an alternative for the diversification of theirs exports baskets. The facilitation of women integration in more value added sectors is one of the objectives of strategies in each country, and services could be the opportunity. Trade liberalisation cannot be expected to eliminate the gender gaps, but Pacific Alliance members are developing different strategies to include women. States should design policies to maximize women's inclusion opportunities as it is clear that this is not a problem that the market will solve on its own.

Taking into account the role trade policy may have on reducing gender disparities, the main questions leading this research are: What are the Pacific Alliance, and its member countries, doing regarding gender and trade policies? Which is the role of trade in reducing the gender gap within the Pacific Alliance?

In order to answer these questions, this paper presents in its first section an overview of the existing relevant literature on trade policy and gender issues, specifically in women economic inclusion aspects. The second section analyses the Pacific Alliance and member countries individual policies on gender inclusion. Finally, we present some conclusions and policy recommendations. 


\section{Trade and Gender}

The link between trade and gender ${ }^{1}$ is a complex and not deeply analysed issue, even less analysed in the case of Latin American countries. Fontana (2009) argues that the interest in the gender effects of trade policies has been growing since the first comprehensive review of empirical evidence in this area, made by Joekes and Weston.

Mainstream economic theory argues that men and women equally benefit from trade liberalisation, this is the trade neutrality assumption (MacLaren, 2012). This work is based on Heckscher and Ohlin, which is the most referred article because of the labour effects studied. The neo-classical theoretical rationale for trade liberalisation is that increased openness to trade is beneficial to economic growth and efficiency, and for these reasons they improve the well-being of a society.

Gender studies within the economic theory are a way to rethink economics in a different way, an emerging field of study (Jacobsenm 1998). Current work in gender economics has identified trade as a possible determinant of female labour force participation (Sauré \& Zoabi, 2014). The main research on the gender dimensions of international trade tends to focus on income and employment rather than on consumption effects, and on the impact of changes in export production rather than on import displacement (Fontana \& Watch, 1998). Literature has augmented in the gender dimensions of trade ${ }^{2}$, increasingly pointed to the ambiguous nature of the impacts (Artecona \& Cunningham, 2002).

The theory that trade is neutral is sustained in the light that pre-existing gender imbalances at the macro, meso and micro ${ }^{3}$ levels determine the differential impact of trade on women and men. The outcome of trade policies could be the same in both groups but their effects over each other depend on the previous and domestic situation of the gender gap.

The real effects are not clear-cut and they often are double edged. On one hand, positive effects on employment, growth and inclusion. Trade can open new opportunities for women's empowerment by opening new markets for their products and by

\footnotetext{
1 Gender refers to the socially constructed roles and behaviours of, and relations between, men and women, as opposed to sex, which refers to biological differences (Randriamaro, 2006).

2 International Gender and Trade Network (IGTN), Women in Development Europe (WIDE) and the Women's Edge Coalition have used impact analysis tools to lever gender considerations into trade agreements.

3 "Macro-level analysis involves examining the gender division of the labour force between the different productive market sectors and the reproductive sectors. Meso-level analysis looks at the institutions that help structure the distribution of resources and activities at the micro-level. It involves examining gender inequalities in public provision as well as gender biases in the rules of operation of labour, commodity and other markets. Micro-level analysis examines in greater detail the gender division of labour, resources and decision-making, particularly within the household" (Fontana, 2009, pp. 2-3).
} 
providing formal employment (UNCTAD, 2017b). Positive effects of trade depend on the implementation or reinforcement of public policies which could help to deal with negative impacts (Eguíluz, Vásquez \& Espino, 2012). A positive relation between the competitiveness of a country and its gender equity condition. On the other hand, the negative effects of gender inequities may act as a constraint to trade expansion; because those factors, that limit individuals from responding to economic opportunities, will constrain the economy's ability to develop. A report by the World Bank and WTO (2015) signals 4 main features of the poor that have a particularly strong impact on their capacity to obtain the full potential benefits of trade: rural poverty; fragility and conflict; informality; and gender.

Women participate less in international trade because they face numerous challenges and obstacles. Evidence shows that there are certain barriers that make it more difficult for women to take advantage of free trade benefits, more general to be part of economic activities. These overlap and enhance one with each other, see box.

Box 1. Barriers for women economic empowerment

- The women reproductive and motherhood roles.

- The natural labour force segregation. Women tend to be clustered in fewer jobs and occupation.

- Less access to acquire better skills that enable to get better jobs. Women's lower education levels and less training, women producers and traders face more constraints in accessing overseas markets than men do.

- The high portion of their time dedicated to housework. Their time constraints prevent them from travelling regularly and long distances to reach the markets that offer best prices and fairer conditions.

- Women's risks related to earnings and employment are higher due to their high participation in the informal sector.

- Women face greater disadvantage than men in responding to new economic incentives, not only because they are more time constrained but also because their access to productive resources is restricted.

- Women in many countries have to deal with cultural biases regarding what is considered appropriate.

- Female traders tend to have weak bargaining power. Less access to financial credit. 
The theory argues that trade or trade liberalization does not have a different impact by gender or race. However, the empirical evidence shows that there are different impacts highly related to previous conditions and context. The effects of trade on a particular individual or group will depend on their position and role in the economy, this is to say, that the impact is mediated by the different roles that men and women have in their countries or societies (Randriamaro, 2006). «The outcomes will differ across countries and regions and are based on the type of economic area and specific sector, measures, timing and sequencing of trade policies. They will also cut across different sectors and subsectors of trade liberalisation: agriculture, services, clothing and textiles, and intellectual property» (Randriamaro, 2006, pp. 5-6).

The problem of gender gap, debated in various forums, has been, among other causes, the result of cultural traditions and ideologies, in which historically women have not been allowed to develop the necessary skills to break through in life, nor to preserve their liberties and their opportunities as a person; this could be deeply analysed for Latin American countries where there is still a lot of prejudices and assigned women roles (Kuper, Nussbaum \& Mustanski, 2012). In addition, in the region, women have not been offered the same opportunities as men to function in the economic and political area (Calvo \& Camacho, 2014).

According to UNCTAD (2011) the effect of trade policy on economic and social activities tend to be different between men and women as they have different economic and social roles and different access to and control over resources, due to socio-cultural, political and economic factors. Evidence again demonstrates that the consequences of a process of trade liberalization on women are context-specific and difficult to generalize, this means you have to study them case by case (UNCTAD, 2017a).

Unfortunately, analyses are still limited principally by the absence of gender-differentiated data in many areas. Also there is a big difficulty to isolate the effects of trade liberalisation from those of other simultaneous changes. In fact, it is quite impossible to separate domestic form international effects, while the first are known to be stronger on gender gap reduction (Fontana, 2009).

There is an increasing common understanding that trade policy is blind and has to move in to be inclusive. «The policies and institutions which govern trade at national, regional and international levels are in fact 'gender blind" (Randriamaro, 2006).

Trade policies are mutually affected by many other domestic and international policies. Exporting companies in developing countries employ more women than non-exporters (World Bank \& WTO, 2015). Jobs in export sectors tend to have better wages than non-exporting. 
Some analysts have further argued that increased participation in the labour market does not automatically bring about an improvement either in women's access to decision-making or in their social rights, as women still face discrimination in the workplace (Villup, 2017).

The long-term goal of transforming gender inequalities remains unmet and appears unattainable without state intervention in markets (Beneria \& Lind, 1995). Therefore, different international organizations have sought to include, among their agreements or objectives, the implementation of the gender perspective as a transversal element within their agendas and working groups.

Organizations and civil society are calling for a halt to the trade reform process until there is a better understanding of its effect on women. However, gender equality objectives are not intrinsically in conflict with trade expansion and therefore there is no a priori reason to oppose trade liberalisation on these grounds (Fontana \& Watch, 1998). Such a case is the one proposed by the Pacific Alliance during the X Summit of the bloc (Pacific Alliance, 2015).

\section{Gender and Pacific Alliance}

Gender inequities do not seem to have market solutions by themselves, the appropriate public policies and their interaction in different levels are fundamental to level the field. Adequate policies could improve women participation in economic activity. Until now, gender equality commitments at the international level often do not translate into domestic laws, or commonly the institutions in charge of promoting gender equality tends to be understaffed, with limited budgets and insufficient political influence (UNCTAD, 2016).

In the last decades, Latin American had a visible improvement on the adoption of normative and public policies aimed to reduce the gap between men and women, and to improve women participation on economic life. The decrease of 12.1 percentage points of the salaries gap between women and men between 1990 and 2014 signifies an advance towards wage equality between women and men in Latin America. However, currently the salary of women is only $84 \%$ of what men earn (CEPAL, 2016). This concern has become a regional challenge not just to reduce the gender gap but also to find new sources of economic growth, encouraging more women to participate in the labour market is a way to do it (Novta \& Wong, 2017). Some Latin American countries, mainly the Pacific Alliance, are in this situation.

The Pacific Alliance (PA) is a regional integration initiative by Chile, Colombia, Mexico and Peru; aim to deepen the integration process among participants by 
speeding up measures for the free circulation of goods and financial flows, the delivery of services and the movement of people across, through the achievement of high standards. First promoted by the former Peruvian President Alan Garcia at the Pacific Forum, it was launched by the Presidential Declaration for the Pacific Alliance (Lima Declaration), in April 2011, and officially established through the Framework Agreement signed in Paranal, Chile, in June 2012. The Framework Agreement of the Pacific Alliance contains the vision, objectives and structure of the block, as well as the parameters for its external linkage (Acosta, Bozzani, García, Portillo \& Fuentes, 2016). The four member countries are likeminded in their economic orientation, its regional integration approach and market oriented policies, largely regarding trade openness and the multiple advantages perceived on it. In this consensus, the worrying gender inequality is one of the common concerns. For this reason, countries of the Alliance, led by Chile, had made important efforts to incorporate gender aspects in the framework of the negotiations of the bloc.

Even though they have done improvements in women economic inclusion, gender equality is still a precarious situation. Although the rate of economic participation of women in Latin America is 52\%, this average is not reached in all the economies of the Pacific Alliance; while in Colombia (58\%) and Peru (61\%) are over the regional average, in Chile (43\%) and Mexico (44\%), there is still much work to be done (OCDE, 2016).

The first and fundamental step is to make an accurate diagnosis of the situation that each of the countries face. OECD made a first sweep of the gender gap, but with little depth and no references to trade aspects (OCDE, 2016). Some of the data are presented in Table I. In PA countries, the emphasis has been placed on the importance of women's entrepreneurial training. In fact, these countries are the best ranked in the region not as a consequence of the PA efforts, in a 0 to 100 scale Chile has 64.8 points, Peru 62.4, Colombia 61.8 and México with 60.2 (Frohmann, 2017). This emphasis could be insufficient since it is a region with very different domestic differences between women, in education, opportunities, etc.

In 2015, during the X Pacific Alliance Summit, gender was officially established as a working issue within the Alliance. In the Paracas Declaration, a «commitment to include gender perspective as a transversal element within the Pacific Alliance work» (Alianza del Pacífico, 2015) was included. In order to develop the gender perspective in the Alliance, a Working Group was established, and a survey on how technical groups should or can incorporate the gender issue in their topics was conducted. During this stage, different diagnoses were made and a road map was defined to be implemented in seven groups. Although none of the selected technical groups refers to fundamental negotiation issues, this becomes a starting point to integrate the subject into negotiations. 


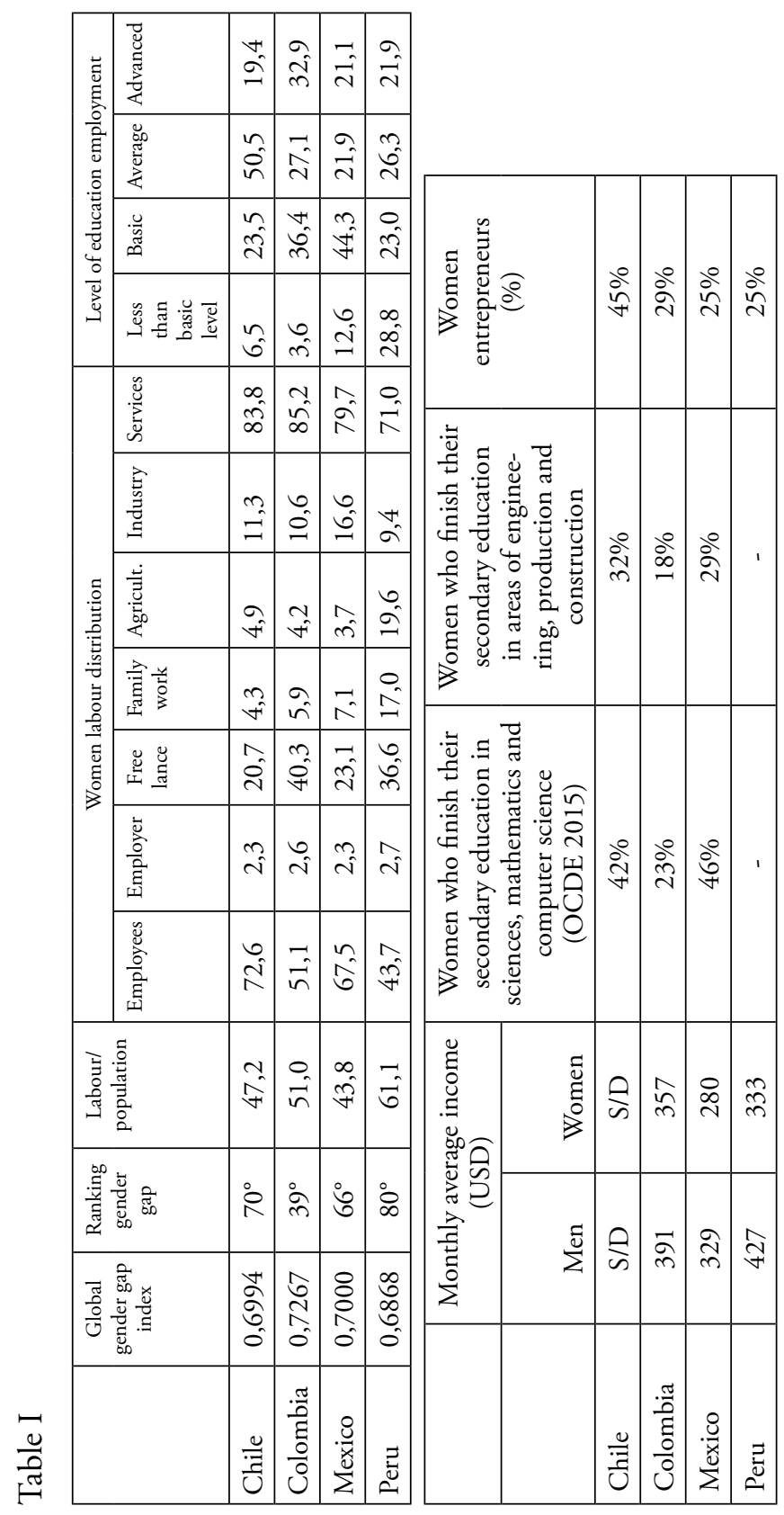


During the XI Summit held in Puerto Varas in 2016, gender was reaffirmed as an important issue for the Alliance, including in its Presidential Mandate three specific points: i) to promote the incorporation of gender perspective in the programs and activities of the Alliance; ii) to implement and develop positive actions like programs that look to incorporate leader women in the export processes; and iii) develop virtual platforms that promote a gender and trade dialogue between member countries.

During the 2017, in the XII Pacific Alliance Summit in Cali, the transverse gender perspective was not only included in the Mandate, but also in the preamble of the Presidential Declaration, showing a political will to advance towards the elimination of gender inequalities. «Our willingness to intensify efforts to mainstream the gender perspective in the programs and activities of the Pacific Alliance, recognizing the important role of women, including women entrepreneurs and entrepreneurs, in the growth and development of our countries, as well as for the fulfilment of the 2030 Agenda for Sustainable Development» (Alianza del Pacífico, 2017b, p. 1). The political will was endorsed by the establishment of a Technical Group within the Pacific alliance institutional framework that replaced the previous working group.

Also it took place the third edition of the meeting of Leadership Entrepreneurs of the Pacific Alliance focused on the economic empowerment of women and business promotion. This forum was created in 2015 in order to foster dynamic trade and investment relationships among women entrepreneurs of the Pacific Alliance countries, while establishing itself as a space to create new businesses and to develop entrepreneurial skills.

Today, the Group is part of the institutional framework, established as Gender and its objective is «to develop a strategy that incorporates the gender perspective as a transversal element within the works of the Pacific Alliance» (Alianza del Pacífico, 2017b). The PA has a High Level Group that supervises the progress of technical groups, studies in which areas to work and elaborates proposals to contact with other organisms or regional groups, particularly from the Asia Pacific region. The aforementioned technical groups negotiate issues related to the topics of the mechanism and they are composed by public servants of the countries members (Acosta et al, 2016). Currently the Alliance has twenty committees, which have different tasks, ranging from studying specific situations, to formulating proposals to advance the process or simply to publicize or promote the Alliance and its advantages. It is evident that all the committees, with the exception of those of Gender and Education, are designed to have an economic impact; even, the Culture Committee (Castaño, 2016).

It is also interesting to acknowledge the private initiatives that have arisen, such as Mujeres del Pacifico (Women of the Pacific) a private organization working on 
gender equity and women entrepreneurship with focus on the four Pacific Alliance countries. It works with a multidisciplinary and diverse team of professional experts in business development, entrepreneurship, innovation, international affairs, trade, among others; with the objective of co-constructing and continuously strengthening the entrepreneur network at the regional level, to expand its social capital and achieve strong connections between them and the entrepreneurship ecosystem.

\section{Policies at the PA countries}

Although the important efforts, made within the Pacific Alliance, to include gender issues in their agendas, most work at the member countries has been done domestically, and due to preexisting conditions, trade policy has not been the main instrument to promote gender equality and reduce the existing gaps. Most domestic policies in the PA countries focus on women economic empowerment, and most of them are still soft law strategies or have a very limited budget in order to achieve severe modification on gender gap persistence. For example, the inclusion of trade and gender chapters in new FTAs is an appreciated pace, however they are still a light component (Zarrilli, 2017).

The debate is how to include gender in free trade agreements to make a difference. On one hand, there is the possibility of making the chapter part of the dispute mechanism; on the other hand, the idea is to include gender issues in all the agreement chapters. However it is not clear yet what kind of dispositions could help to reduce the gender gap and empower women and not become a barrier to trade.

This does not mean that the work that has been done in this area is not important, at least the countries have placed the problem in their agendas, and this will help actors to move forward. The assumption of the gap as a challenge in any area, as trade, will be determinant to tackle it in a mid-term period. There seems to be a growing consensus, not effective yet, that it is crucial to promote gender equity policies alongside trade promotion policies. All the efforts could become effective strategies to help women take advantage of the opportunities created by trade liberalization.

The four countries address the relevance of domestic active gender gap reduction policies in many sectors; they have gender guidelines or comprehensive laws from highlevel authorities. They are all emphasizing the relevance of the information on women unequal opportunities and the gap reduction as part of their development strategy.

In this section, we present the trade women oriented policies of each country, not all polices have a gender component. In this section we review just those directly imposed to trade or by trade responsible institutions. 


\section{Chile}

For Chile, the presidency of Michelle Bachelet (2014-2018) has led to a preeminence of gender perspective within the public administration and public policy formulation. Although Chilean policies are mainly oriented to women economic empowerment, entrepreneurship, rural development and access to financial sector, trade policy and export promotion have not been left aside, and Chile has incorporated gender as a trade relevant issue in the last years.

The General Directorate of International Economic Relations (DIRECON) in 2016, formed the Ministry of Foreign Relations, the institution responsible for trade policy established a Gender Department responsible to make the follow-up of gender topics, enhance internal gender policies and to manage the programs to promote and support women participation in international trade.

The most interesting outcomes of this gender perspective work have been the inclusion of gender chapters within free trade agreements, specifically with Uruguay, Canada and Argentina. They mainly make reference to the implementation of gender equality commitments included in global conventions, with no specific commitments. There is no requirement of equivalence or harmonization regarding any gender approach between them, and they do not consider specific sector benefits for women, for example (UNCTAD, 2017a). All of them are soft law approach where dispute settlement mechanisms do not apply. Despite this, they became a first stage for the inclusion of this topic in future negotiations, and one could think they will take a similar path to labour or environmental chapters, which at first where included as side chapters in most FTA, and now are becoming core part of them.

On trade promotion policies, ProChile has included gender perspective and specific programs aimed to boost women participation in international trade. MUJEREXPORTA is the flagship program in this sense, which aims to help women's businesses to join the export activity. With this objective, a set of training and promotion actions were carried out in 2017, benefiting more than 800 businesswomen in the promotion of their products overseas.

DIRECON published in 2017 the First Scan of Women Exporters in order to contribute to quantitative analysis to design better public policies. The document is organized in two sections, the first devoted to the statistical analysis of the participation of women in the export activity in Chile. In the second, the main antecedents of the participation of women in world trade are compiled, through studies carried out by the main international organizations (DIRECON, 2017). 


\section{Mexico}

In Mexico the responsible entity for trade is the Economy Secretariat, but the gender inclusion strategy is defined at a higher level, in the National Development Plan 2007-2012. Mexico has the laws for gender equality Ley para la Igualdad entre Mujeres y Hombres from 2006 and Ley General de Acceso de las Mujeres a una Vida Libre de Violencia from 2007. And the recent National program for equality and non- discrimination 2014-2018 (PRONAIND) is mandatory for all the public administration; it contains specific lines in gender issues.

These laws demand actions at the federal level to promote a life without violence or discrimination, as well as an authentic culture of equality, in this sense the gender perspective is transversally incorporated in each one of its axes.

There is not a formal chapter in any of its trade agreements, but Canada mentioned that they will likely include gender aspects in the NAFTA 2.0; with the objective of adopting cooperation mechanisms to promote gender equality by each of the members of the agreement; Mexican institutions agreed with the Canadian proposal.

\section{Box 2. Chile-Mexico Cooperation Fund}

There is also a bilateral effort between Chile and Mexico, the project of «Economic Empowerment: Participation of Women Entrepreneurs in Foreign Trade» as part of the Joint Chile-Mexico Cooperation Fund. The main objective of the project is to encourage the participation of women entrepreneurs in foreign trade. Through the activities proposed in the framework of the project, it is intended to increase the possibilities to access and / or consolidate their participation in foreign trade. Finally, the IDB is developing a study to identify the main barriers that women face in both countries.

\section{Colombia}

Similar to Mexico, Colombia has a higher-level strategy that was reaffirmed by President Santos, Presidential Counsellor for Women Equity. The trade-oriented policies are sectorial and aim to improve insertion of those gender intensive sectors or the PA participation, in the different women activities that have been developed. In the case of Colombia, private initiatives are evident, such as dialogues and summits managed by the National Association of Women Entrepreneurs and Entrepreneurs of Colombia.

The main policies are directed to rural development and gender equality ${ }^{4}$. As an example, there is the Women Coffee Growers Program developed by the Colombian

\footnotetext{
4 https:/www.minagricultura.gov.co/tramites-servicios/desarrollo-rural/Paginas/v1/Programa-mujer-rural.aspx
} 
Coffee Growers Federation, which attempts to implement gender equity in the coffee industry.

Colombia, as the rest of the PA countries, has a much liberalized trade orientation, its free trade agreements benefited some of the extensive female labour force participation as textile and clothing industry and flowers industry. However, its first gender chapter could be the one with the PA.

\section{Peru}

Peru also defined a high level approach in the Law 28983 - Law on equal opportunities for women and men, which encourages all the governmental institutions to work on gender gap reduction strategies.

The most evident trade policy is the "Women Export Leaders Program"», which started in 2017 with the program «She Exports» implemented by the Commission for the Promotion of Peru for Exports and Tourism PROMPERÚ. The main objective of the project is to promote the business development of Peruvian women exporters, strengthening their skills and developing their entrepreneurial qualities, in addition to contribute to social and economic empowerment by promoting entrepreneurship led by women, in order to reduce job gaps, at the same time to incorporate women into the activity. This is a special program which offers training and technical assistance to women entrepreneurs.

In Peru, the PROMPERU trade promotion agency has developed an information platform with data on export companies. This platform identified women-led companies by cross-referring its own data with statistics from Customs and the records of the Ministry of Production.

They do not have a proper chapter on the FTA, but with Canada Peru liberalized some relevant products from a gender perspective including textiles and clothing, tariffs of which were reduced from 16.1 per cent to zero, and footwear, tariffs of which were lowered from 13.5 per cent to zero.

Their work at multilateral level could be noticed in APEC and WTO. APEC 2019 will take place in Chile, who is the country that will suggest the relevant issues for the meeting, highlighting gender and trade. The multilateral trade institutions are also working on this direction, the four countries belong to the WTO and they are part of the Buenos Aires Declaration on Women and Trade (2017), Colombia is not in

\footnotetext{
5 http://repositorio.promperu.gob.pe/repositorio/bitstream/handle/123456789/2157/Programa_Mujeres_ Lideres_exportadoras_2017_keyword_principal.pdf?sequence $=1$ \&isAllowed $=y$
} 
APEC, but the rest have been doing an active work in this direction. OCDE is also collocating gender as a centre action.

\section{Conclusions}

Gender unequal opportunities and discrimination are a PA pending issue. The trade perspective on gender gap is being addressed by the four countries. The efforts are still insufficient, but they could define some standard and they have positioned this topic as relevant in a deeply unequal region.

The policies mentioned in the paper are clearly diffuse and soft. This could be because there is not a clear idea of how to tackle the issue and a big uncertainty about how countries could deal with international commitments in gender aspects even at a domestic level. There is also a perception that gender issues could become a barrier to trade if some countries will want to use it.

The public policies have an essential role to reduce the gender gap in trade opportunities and this will have a direct impact on growth and development. Is nearly impossible to believe inequalities will disappear solely due to market forces or just due to trade liberalization.

It is relevant that trade policies consider that is necessary to have specific genderrelated standards as equal pay for equal work; that there is no reason that the dispute settlement resolution chapter should not apply to gender chapter. They have to design agreements to empower women to include them in economic activities.

The work of the PA countries and those that are in the process of adhesion, are in the right direction, and they should continue working on it. The support of the multilateral institutions will be determinant in trade and gender positive relation.

For this is fundamental to work on more analysis in this area, how trade is related, the role of trade policies, what kind of provisions or measures should trade agreements consider and how gender issues will not become an undercover barrier to trade.

Traditionally, trade policy has been perceived as gender neutral, although pre-existing domestic conditions may differ the impact of trade liberalization amongst genders. "Increasing recognition of the different effects of trade on women compared to men, and improving the extent to which women are consulted on trade policies and their implementation, can help increase the poverty impact of trade» (World Bank \& WTO, 2015). For developing countries, especially those that have recognized a possibility to promote their economic development in trade, understanding gender impact of trade policies becomes an important instrument to reduce gender inequalities. 
- The persistent barriers for women have to be studied deeply in its contextual form. A better understanding of the gender dimension of trade agreements could help to contribute to better policy making.

- There is a particular need for more gender-disaggregated data to understand the participation of women in the economy and the links between gender and poverty.

- Trade liberalization cannot be expected to eliminate the gender wage gap. The growing literature on gender aspects of trade liberalisation does not yet provide straightforward answers as to how women and men are affected by trade

- The gender issues are not treated in a systematic manner; they should be part of a continuous work.

- The PA countries have a worrying and unstable situation regarding women inclusion in economic activity. There seem to be an intention of addressing gender and trade from Paracas Declaration. The Programs in the PA are women not gender.

- Individually, there are different levels of domestic advances in gender inclusion. Domestic policies oriented to reduce gender gaps vary between PA economies.

- Currently, programs implemented to promote gender equality are not sectorial, they are general. The identification of sectors that could reduce gender gaps may allow the formulation of tailored policies, and they can have an increased impact over gender gaps and poverty alleviation.

- Services could be an opportunity for women inclusion in international trade. The PA framework may become a space to advance in gender-inclusive trade policies.

- The Pacific Alliance progress in women's empowerment could create a competitive advantage in the Latin American region.

\section{References}

Acosta, G. Bozzani, A. García, C. Portillo, P. \&Fuentes, D. (2016). La Alianza del Pacifico: un nuevo marco de comercio regional. Documentos técnicos del OREI. From http://sedici. unlp.edu.ar/bitstream/handle/10915/62224/Documento_completo.pdf-PDFA. pdf?sequence $=1$

Alianza del Pacífico (2015). Declaración de Paracas. From http://www.sice.oas.org/TPD/ Pacific_Alliance/Presidential_Declarations/X_Paracas_Declaration_s.pdf

Alianza del Pacífico (2017a). ABC de la Alianza del Pacifico. From https://alianzapacifico. net/?wpdmdl $=4441$

Alianza del Pacífico (2017b). Declaración de Cali. From https://alianzapacifico.net/download/ declaracion-de-cali-junio-30-de-2017/ 
Artecona, R. \& Cunningham, W. (2002). Effects of trade liberalization on the gender wage gap in Mexico. Washington D.C.: World Bank.

Beneria, L. \& Lind, A. (1995). Engendering international trade: concepts, policy, and action: Gender, Science and Development Programme (GSD). The Gender, Science and Development Programme and the United Nations Development Fund for Women.

Calvo, G. \& Camacho, R. (2014). La violencia de género: evolución, impacto y claves para su abordaje. Enfermería Global, 13(33), 424-439. https://doi.org/10.6018/ eglobal.13.1.181941

Castaño, J. (2016). Análisis y perspectivas de la Alianza del Pacífico. Estudios de Deusto, 64(1), 281-305. https://doi.org/10.18543/ed-64(1)-2016pp281-305

CEPAL. (2016). Persiste la brecha salarial entre hombres y mujeres. Santiago de Chile: Observatorio de Igualdad de Género de América Latina y el Caribe.

DIRECON. (2017). Primera radiografía a la participación de las mujeres en las exportaciones chilenas. Santiago de Chile: Gobierno de Chile.

Eguíluz, A. Vásquez, M.I. \& Espino, A. (2012). Trade and Gender: Advances in the Process of Gender Mainstreaming in Trade Operations. Washington D.C.: Inter-American Development Bank.

Fontana, M. (2009). The gender effects of trade liberalization in developing countries: a review of the literature. In M. Bussolo \& R.E. De Hoyos. Gender Aspects of the Trade and Poverty Nexus. A Macro-Micro Approach (pp. 25-50). Washington D.C: Palgrave Macmillan.

Fontana, M. \& Wacht, E. (1998). Global trade expansion and liberalization: gender issues and impacts. Brighton: Institute of Development Studies.

Frohmann, A. (2017). Gender Equality and Trade Policy. SECO Working Paper, 24. From https:// www.wti.org/media/filer_public/8b/a8/8ba88d03-1a2b-4311-af6a-629d9997c54c/ working_paper_no_24_2017_frohmann.pdf

Jacobsen, J. (1998). The economics of gender. Massachusetts: Blackwell Malden.

Kuper, L. Nussbaum, R. \& Mustanski, B. (2012). Exploring the diversity of gender and sexual orientation identities in an online sample of transgender individuals. Journal of Sex Research, 49(2-3), 244-254. https://doi.org/10.1080/00224499.2011.596954

MacLaren, B. (2012). Free trade agreements in Peru and Colombia: monitoring future impacts from a gender perspective. Ottawa: North-South Institute.

Novta, N. \& Wong, J. (2017). Women at Work in Latin America and the Caribbean. Washington D.C.: International Monetary Fund.

OCDE. (2016). Gender equality in the Pacific Alliance. París: OECD Publishing. https://doi. org/10.1787/9789264262959-en

Randriamaro, Z. (2006). Gender and trade. Brighton: Institute of Development Studies.

Sauré, P. \& Zoabi, H. (2014). International trade, the gender wage gap and female labor force participation. Journal of Development Economics, 111, 17-33. https://doi. org/10.1016/j.jdeveco.2014.07.003 
UNCTAD. (2011). Gender Equality \& Trade Policy. Geneva: United Nations Inter-Agency Network on Women and Gender Equality (IANWGE).

UNCTAD. (2016). Trade, gender and development. Geneva: UNCTAD.

UNCTAD. (2017a). The new way of addressing gender equality issues in trade agreements: Is it a true revolution? Geneva: UNCTAD. From http://unctad.org/en/PublicationsLibrary/ presspb2017d2_en.pdf

UNCTAD. (2017b). Trade and Gender Toolbox. Geneva: UNCTAD. From http://unctad. org/en/PublicationsLibrary/ditc2017d1_en.pdf

Villup,E. (2017). TheEU'sTradePolicy:fromgender-blindtoogender-sensitive?Brussels:Directorate for External Policies European Parliament. From http://www.europarl.europa.eu/ RegData/etudes/IDAN/2015/549058/EXPO_IDA(2015)549058_EN.pdf

World Bank. (1994). Enhancing women's participation in economic development. Washington D.C.: International Bank for Reconstruction and Development \& World Bank.

World Bank \& WTO. (2015). The role of trade on reducing poverty. Washington D.C. From http://documents.worldbank.org/curated/en/726971467989468997/pdf/97607REPLACEMENT-The-Role-of-Trade-in-Ending-Poverty.pdf

WTO. (2017). Gender Aware Trade Policy. Geneva: World Trade Organization. From https:// www.wto.org/english/news_e/news17_e/dgra_21jun17_e.pdf

Zarrilli, S. (2017). The gender chapters in trade agreements: A true revolution? ICTSD's network of experts. From https:/www.ictsd.org/opinion/ the-gender-chapters-in-trade-agreements-a-true-revolution

Fecha de recepción: 16 de marzo de 2018 Fecha de aprobación: 14 de junio de 2018 